\title{
KEANEKARAGAMAN JENIS GASTROPODA PADA EKOSISTEM HUTAN MANGROVE DESA SEBUBUS KECAMATAN PALOH KABUPATEN SAMBAS
}

(Species diversity of gastropods in the mangrove forest ecosystem in Sebubus village Paloh District Sambas Regency)

\author{
Lisa Ernawati, M. Sofwan Anwari, M. Dirhamsyah \\ Fakultas Kehutanan Universitas Tanjungpura Pontianak, Jl. Daya Nasional Pontianak 78124 \\ Email: lisaernawati25@gmail.com
}

\begin{abstract}
Gastropod is one the mollusk phylum that can adapted at the mangrove ecosystem. Gastropod are organisms that have an ecological role as forming detritus. The study aimed to examine species diversity of gastropods in the mangrove forest ecosystem of Sebubus Village, Paloh District, Sambas Regency. The study was conducted in April 2019, using the survey method. Observations found 6 families and 16 species of gastropods in the mangrove ecosystem. Gastropods species are Chicoreus capucinus, Nerita balteata, Neritina cornucopia, Nerita violacea, Cerithideopsilla alata, Cerithidiopsis quoyii, Cerithidea obtusa, Littoraria scabra, Littoraria undulata, Littoraria carinifera, Nassarius dorsatus, Cassarius dorsatus, Cassidula aurisfelis, Ellobium aurisjudae, Cassidula nucleus, Pythia plicata, and Ellobium gangeticum. Species diversity index of gastropod in zone $1=0.83$, zone $2=0.73$ and zone $3=0.79$ in the low category. Species abundance index of gastropod in zone $1=15.3$, zone $2=10.5$, zone $3=$ 15.8. Species evenness index of gastropod in zone $1=0.32$, zone $2=0.30$ and zone $3=0.30$ categorized as low. Species dominance index of gastropod in zone $1=0.20$, zone $2=0.28$ and zone $3=0.25$ are categorized as low. Species similiarity index of gastropod in zone 1 and $2=$ $91.67 \%$, zone 2 and $3=80.00 \%$, zone 1 and $3=81.48$ are categorized very high.
\end{abstract}

Keywords: Diversity, Gastropods, Mangrove Ecosystems

\section{PENDAHULUAN}

Gastropoda adalah salah satu organisme yang mempunyai peran ekologis sebagai pembentuk detritus dalam menguraikan daun-daun mangrove yang telah gugur, batang dan pohon yang sudah mati. Gastropoda juga berperan penting dalam menjaga keseimbangan ekologi pesisir pantai, umumnya pada ekosistem mangrove (Zulheri et al., 2014).

Keanekaragaman jenis gastropoda dapat menggambarkan kondisi perairan, serta berperan penting dalam menjaga keseimbangan ekologi di ekosistem hutan mangrove. Keberadaan gastropoda pada ekosistem hutan mangrove berperan dalam dinamika unsur hara, daun mangrove yang gugur tidak langsung mengalami pelapukan atau pembusukan oleh mikroorganisme, tetapi memerlukan bantuan hewan-hewan yang disebut makrobenthos, salah satunya adalah gastropoda (Yanto et al., 2016).

Hutan mangrove di Desa Sebubus Kecamatan Paloh Kabupaten Sambas merupakan hutan mangrove yang masih alami dikelola oleh kelompok masyarakat Kalilaek dan Green Leaf. Keberadaan hutan mangrove sudah mulai berkurang akibat pembukaan lahan untuk pertanian 
dan tambak di sekitar kawasan hutan mangrove. Faktor lainnya yaitu penebangan mangrove untuk dijadikan kayu bakar, bahan bangunan dan pembukaan saluran sungai.

Penelitian mengenai keanekaragaman gastropoda pada ekosistem hutan mangrove Desa Sebubus merupakan penelitian dasar yang belum pernah dilakukan. Tujuan penelitian adalah mengkaji keanekaragaman jenis gastropoda pada ekosistem hutan mangrove Desa Sebubus Kecamatan Paloh Kabupaten Sambas.

Penelitian ini diharapkan dapat memberikan data dan informasi mengenai keanekaragaman jenis gastropoda sehingga dapat digunakan sebagai panduan dalam mengelola serta memanfaatkan gastropoda pada ekosistem hutan mangrove Desa Sebubus Kecamatan Paloh Kabupaten Sambas.

\section{METODE PENELITIAN}

Penelitian dilakukan pada bulan April 2019 di kawasan ekowisata hutan mangrove Desa Sebubus Kecamatan Paloh Kabupaten Sambas yang mempunyai luasan $\pm 35 \mathrm{Ha}$. Bahan dan alat yang digunakan adalah peta lokasi, meteran, tali rapia, parang, buku identifikasi, kamera hp, kertas label, botol sampel, tally sheet, plastik sampel, transek kuadran 1 x 1 m, thermo hygro, refraktometer, soil tester, sampel gastropoda, dan alkohol $70 \%$.
Metode yang digunakan adalah metode survei. Penentuan lokasi penelitan dilakukan secara purposive sampling (Fachrul, 2007). Metode pembuatan jalur sampling yang digunakan dalam penelitian yaitu metode line transect (Anwar et al., 1984). Penentuan lokasi penelitian dibagi menjadi 3 zona pengamatan. Zona 1 berada di zona proksimal (depan) dekat dengan muara sungai, zona 2 berada di zona middle (tengah) berada diantara zona proksimal dan zona distal, zona 3 berada di zona distal (belakang) dekat dengan vegetasi darat. Setiap zona dibuat 10 plot dengan total keseluruhan 30 plot disemua zona. Jarak antar plot tidak ditentukan karena peletakan plot dilakukan secara purposive sampling.

Pengambilan sampel gastropoda dilakukan pada saat air surut. Sampel gastropoda yang berada dalam petak kuadrat berukuran $1 \times 1 \mathrm{~m}$. diambil secara langsung dengan menggunakan tangan (Hand collecting), baik yang berada di permukaan substrat maupun akar, batang dan daun.

Identifikasi jenis gastropoda dilakukan dengan melihat bentuk cangkang, warna, corak dan jumlah putaran cangkang. Setiap jenis yang ditemukan dicocokan karakteristik morfologi dengan melihat pada buku identifikasi (The Living Marine Resources of The Western Central Pacific volume 1. Seaweeds, corals, bivalves and gastropods). 


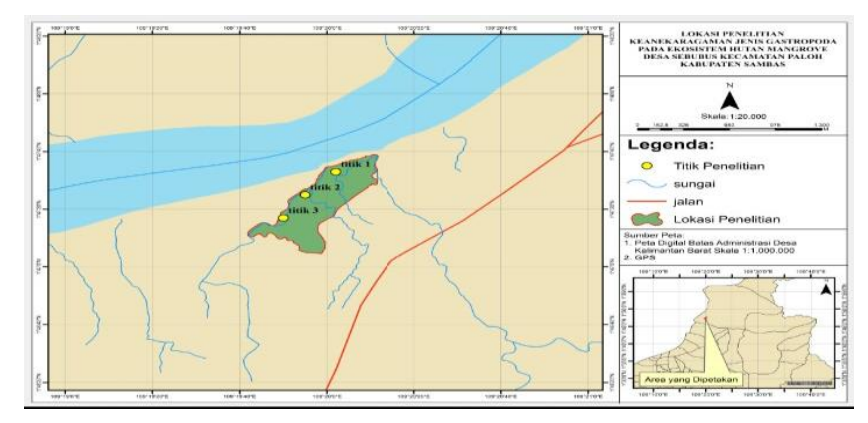

Gambar 1. Peta lokasi penelitian pada hutan mangrove Desa Sebubus (Maps of

\section{Analisis Data} research location in the mangrove forest of Sebubus Village)

Parameter yang digunakan dalam perhitungan analisis data adalah

1. Indeks Keanekaragaman

Keanekaragaman jenis dihitung berdasarkan indeks keanekaragaman (Shannon- Wiener, 1963)

2. Kelimpahan Jenis

Kelimpahan jenis merupakan banyaknya jenis gastropoda yang ditemukan pada setiap stasiun/titik sampel, di hitung berdasarkan rumus (Odum 1996).

3. Indeks Kemerataan Jenis

Kemerataan jenis digunakan untuk mengetahui gejala dominasi diantara setiap jenis dalam suatu lokasi, dihitung dengan menggunakan rumus (Odum,1996).

4. Indeks Dominansi
Dominasi spesies tertentu diketahui dengan indeks dominansi Simpons (Odum, 1996).

5. Indeks Kesamaan Jenis Indeks kesamaan jenis digunakan untuk membandingkan antar zona pengamatan. Menghitung indeks kesamaan (IS) antara dua zona dapat digunakan rumus Sorensen (Odum, 1996).

\section{HASIL DAN PEMBAHASAN}

Jenis-Jenis Gastropoda di Setiap Jalur penelitian

Hutan mangrove di Desa Sebubus tidak berhadapan langsung dengan laut, tetapi berhadapan langsung dengan muara sungai. Berdasarkan hasil penelitian, jenis-jenis gastropoda yang ditemukan pada ekosistem hutan mangrove Desa Sebubus Kecamatan Paloh Kabupaten Sambas terdiri atas 6 famili dan 16 spesies. 
Tabel 1. Rekapitulasi Jenis Dari Jumlah Gastropoda yang Terdapat di Setiap Zona Penelitian (Recapitulation of Gastropods Species Found on Each Zone Pathway)

\begin{tabular}{|c|c|c|c|c|c|c|}
\hline \multirow[t]{2}{*}{ No } & \multirow[t]{2}{*}{ Famili } & \multirow[t]{2}{*}{ Spesies } & \multicolumn{3}{|c|}{ Jumlah Individu /Zona } & \multirow[t]{2}{*}{$\begin{array}{c}\text { Jumlah } \\
\text { Total }\end{array}$} \\
\hline & & & 1 & 2 & 3 & \\
\hline 1 & Muricidae & Chicoreus capucinus & 16 & 1 & 5 & 22 \\
\hline 2 & \multirow{3}{*}{ Neritidae } & Nerita balteata & 39 & 3 & 1 & 43 \\
\hline 3 & & Neritina cornucopia & 7 & 2 & - & 9 \\
\hline 4 & & Nerita violacea & 3 & 3 & 1 & 7 \\
\hline 5 & \multirow[t]{3}{*}{ Potamididae } & Cerithideopsilla alata & 5 & 3 & 6 & 14 \\
\hline 6 & & Cerithidiopsis quoyii & 2 & - & - & 2 \\
\hline 7 & & Cerithidea obtuse & 1 & 6 & 11 & 18 \\
\hline 8 & \multirow[t]{3}{*}{ Littorarinide } & Littoraria scabra & 25 & 21 & 4 & 50 \\
\hline 9 & & Littoraria undulata & 3 & 4 & 1 & 8 \\
\hline 10 & & Littoraria carinifera & - & - & 1 & 1 \\
\hline 11 & Nassariidae & Nassarius dorsatus & - & - & 2 & 2 \\
\hline 12 & \multirow{5}{*}{ Ellobiidae } & Cassidula aurisfelis & 46 & 50 & 69 & 165 \\
\hline 13 & & Ellobium aurisjudae & 1 & 2 & 2 & 5 \\
\hline 14 & & Cassidula nucleus & 3 & 10 & 23 & 36 \\
\hline 15 & & Pythia plicata & 2 & - & 7 & 9 \\
\hline 16 & & Ellobium gangeticum & - & - & 25 & 25 \\
\hline & \multirow{2}{*}{\multicolumn{2}{|c|}{$\begin{array}{l}\text { Jumlah } \\
\text { Jumlah Jenis }\end{array}$}} & 153 & 105 & 158 & 416 \\
\hline & & & 13 & 11 & 14 & \\
\hline
\end{tabular}

Keterangan: Zona $1=$ Proksimal, Zona $2=$ middle, Zona $3=$ distal .

Berdasarkan data tabel 1 diketahui jumlah individu gastropoda yang banyak ditemukan adalah dari famili Ellobiidae. Hidup diperairan dangkal, intertidal laut dan sebagian kecil jenis hidup terrestrial (dipermukaan tanah). Famili Ellobiidae yang ditemukan pada hutan mangrove Desa Sebubus yaitu Cassidula aurisfelis, Ellobium aurisjudae, Cassidula nucleus, Pythia plicata, dan Ellobium gangeticum.

Famili Nassariidae merupakan jenis gastropoda yang paling sedikit ditemukan pada lokasi penelitian. Menurut penelitian Islami (2015) famili Nassariidae merupakan gastropoda yang hidup di padang lamun, ditemukan pada daun-daun lamun. Daun lamun dapat disebut mikrohabitat bagi jenis gastropoda Nassarius dorsatus.

Famili Muricidae biasa disebut keong kodok. Kebanyakan hidup di perairan dangkal dan bersifat karnivora yang memakan bermacam jenis cacing, dengan cara melumpuhkan dengan sekresi asam dan mencernanya secara langsung.

Famili Neritidae hidup di laut, pantai ataupun lumpur merupakan predator bivalvia dan gastropoda jenis lainnya dengan mengebor lubang sirkulasi sehingga siap memangsa dengan menggunakan kelenjar sekresi. Hidup di laut, air tawar maupun terrestrial.

Famili Potamididae sangat berlimpah di mangrove dan laut yang berlumpur pada daerah beriklim tropis dan subtropis. 
Famili Potamididae yang ditemukan pada hutan mangrove Desa Sebubus hanya sedikit, karena jenis gastropoda seperti Cerithideopsilla alata, Cerithidiopsis quoyii, Cerithidea obtuse, diambil oleh masyrakat sekitar untuk dikonsumsi dan dijual.

Famili Littorarinide merupakan siput laut yang sangat kecil bersifat herbivora. kebanyakan hidup di daerah intertidal, beberapa jenis hanya dapat ditemukan ketika pasang maksimal. Famili Littorarinide yang paling banyak ditemukan pada hutan mangrove Desa Sebubus yaitu Littoraria scabra. Habitat jenis ini melimpah ditemukan di hutan nipah, di rawa-rawa dan di tepi arah laut dari kawasan mangrove.

Gastropoda yang berada di kawasan mangrove Desa Sebubus Kecamatan Paloh Kabupaten Sambas dapat dikelompokan menjadi tiga yaitu gastropoda asli mangrove, gastropoda fakultatif, dan gastropoda pengunjung (Rusnaningsih, 2012).

Kelompok gastropoda asli mangrove, yaitu jenis gastropoda yang seluruh atau sebagian besar hidupnya dihabiskan di ekosistem mangrove sehingga kepadatanya cukup tinggi. Jenis-jenis gastropoda tersebut sangat jarang ditemukan di luar ekosistem. Sebagian besar gastropoda tersebut merupakan pemakan serasah dan banyak dijumpai di bagian tengah dan belakang hutan mangrove. Jenis gastropoda yang tergolong asli mangrove yaitu Cerithideopsilla alata, Cerithidiopsis quoyii, Cerithidea obtusa, Cassidula aurisfelis, Ellobium aurisjudae Cassidula nucleus Pythia plicata dan Ellobium gangeticum. Jenis gastropoda asli mangrove merupakan pemakan serasah mangrove, hanya beberapa jenis yang tergolong predator. Menurut Poutiers (1998) jenis gastropoda dari famili Muricidae merupakan jenis gastropoda yang aktif sebagai predator yaitu jenis gastropoda Chicoreus capucinus.

Kelompok gastropoda fakultatif yaitu jenis-jenis gastropoda yang menggunakan ekosistem mangrove sebagai salah satu tempat hidupnya. Jenis-jenis gastropoda tersebut memiliki frekuensi dan kepadatan tinggi hanya apabila kondisi memungkinkan untuk hidupnya. Kelompok gastropoda fakultatif yang ditemukan adalah dari famili Littorinidae, yaitu Littoraria scabra, Littoraria undulata dan Littoraria carinifera. Ketiga jenis Gastropoda ini dapat bergerak bebas pada batang dan daun mangrove. Jenisjenis gastropoda dari suku Littorinidae merupakan pemakan mikroflora yang ada di kulit kayu dan daun-daun mangrove (Rusnaningsih, 2012). Menurut Tapilatu dan Pelasula (2012) bahwa biota penempel pada mangrove didominasi oleh famili Littorinidae.

Kelompok gastropoda pengunjung yaitu gastropoda yang secara tidak sengaja ada di dalam ekosistem mangrove sehingga memiliki frekuensi dan kepadatan yang rendah. Kelompok tersebut umumnya hidup di area sempit disekitar perbatasan dengan ekosistem lain, yaitu di bagian muka hutan yang berbatasan dengan daratan. Kelompok gastropoda pengunjung yang ditemukan dari famili Muricidae yaitu Chicoreus 
capucinus dan famili Neritidae yaitu Nerita balteata, Neritina cornucopia, dan Nerita violacea. Menurut Nurrudin (2015) Chicoreus capucinus merupakan pengunjung dalam hutan mangrove karena habitat aslinya di daerah pecahan karang atau pasir. Jenis-jenis gastropoda dari famili Neritidae merupakan gastropoda air

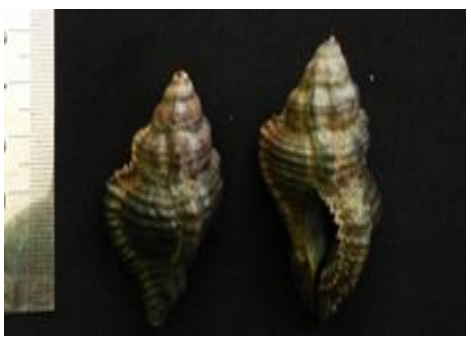

a. Chicoreus capucinus

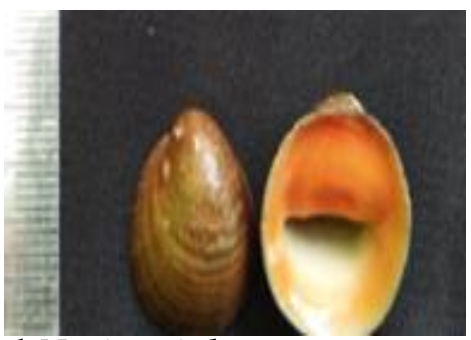

d.Nerita violacea

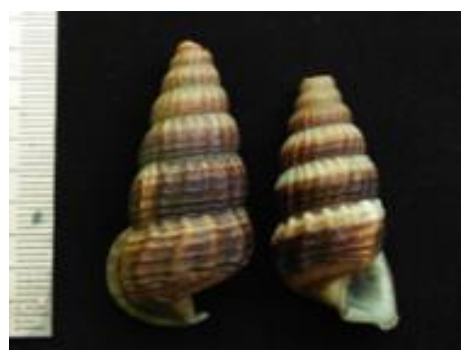

g. Cerithidea obtusa

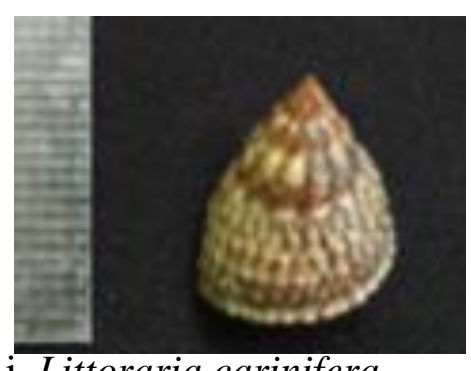

j. Littoraria carinifera

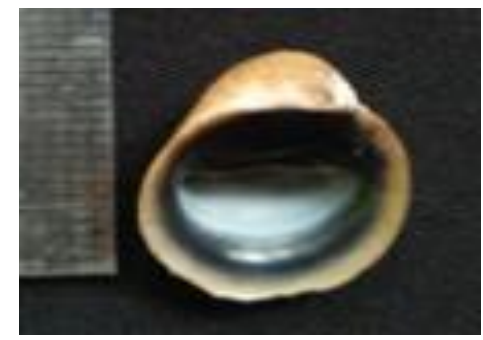

b. Nerita balteata

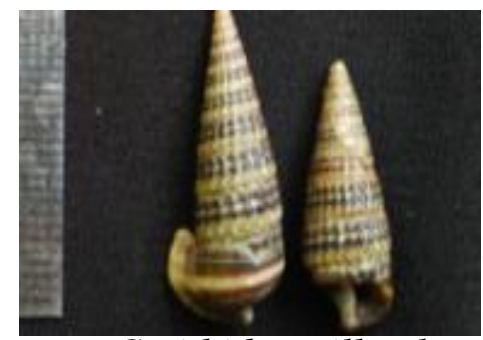

e. Cerithideopsilla alata

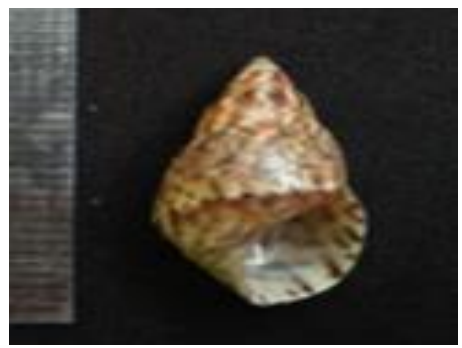

h. Littoraria scabra

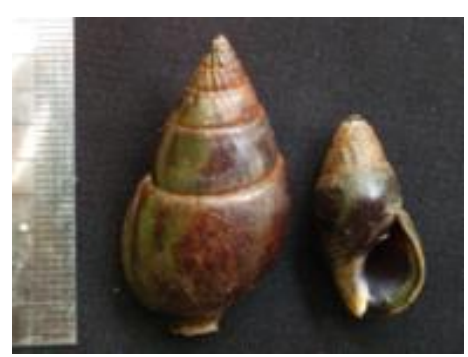

k. Nassarius dorsatus

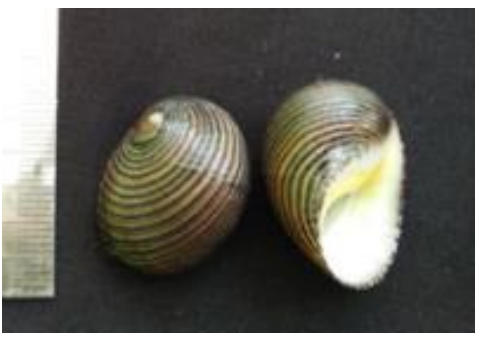

c. Neritina cornucopia

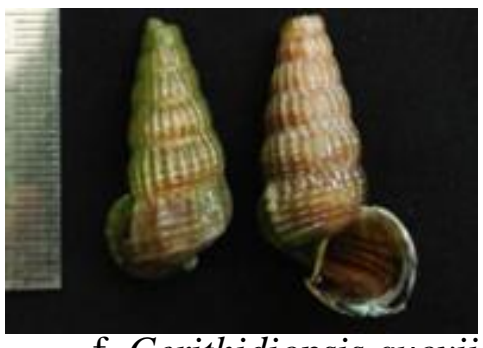

f. Cerithidiopsis quoyii

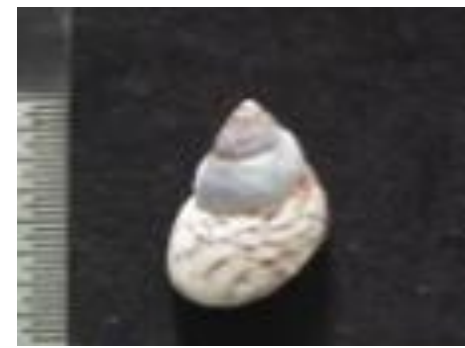

i. Littoraria undulata

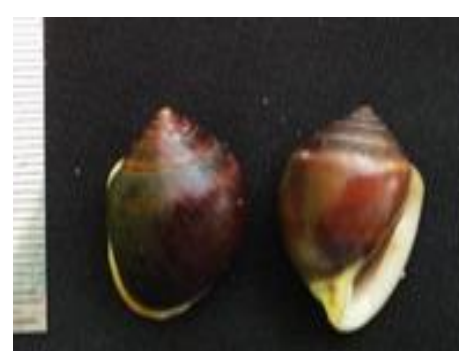

1. Cassidula aurisfelis 


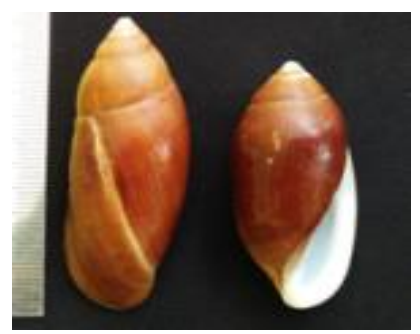

m. Ellobium aurisjudae

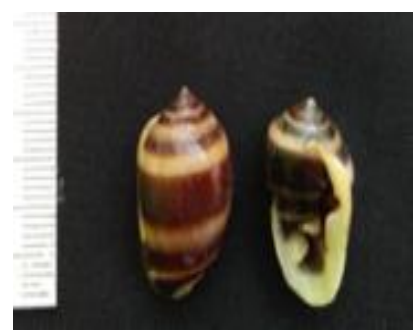

n. Cassidula nucleus

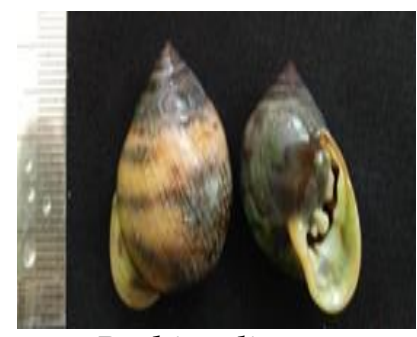

o. Pythia plicata

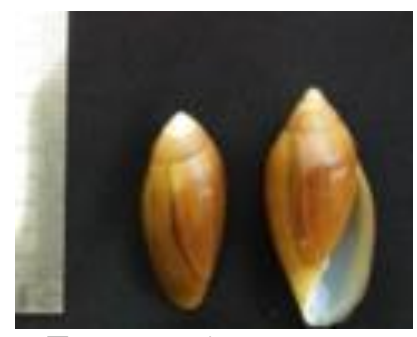

p. E. gangeticum

Gambar 2. Jenis-Jenis Gastropoda pada Hutan Mangrove Desa Sebubus (Species of gastropods in the mangrove forest of Sebubus Village)

Tabel 2 Nilai Rata-Rata Faktor Lingkungan Abiotik yang diperoleh pada Setiap Zona di Hutan Mangrove Desa Sebubus Kecamatan Paloh Kabupaten Sambas ( The Average Value of Abiotic Environmental Factors Obtained in Each Zone in the mangrove forest in the village of sebubus, Paloh District Sambas Regency)

\begin{tabular}{llccc}
\hline No & Faktor Lingkungan & Zona 1 & Zona 2 & Zona 3 \\
\hline 1 & Intensitas Cahaya (Lux) & 2119,7 & 2251,3 & 2209,3 \\
2 & Kelembaban Udara (\%) & $79 \%$ & $85 \%$ & $71 \%$ \\
3 & Suhu Tanah $\left({ }^{\circ} \mathrm{C}\right)$ & 29 & 28 & 27 \\
4 & pH & 5,7 & 5,5 & 5,3 \\
5 & Salinitas $(\%)$ & 15,7 & 14 & 13,3 \\
6 & Suhu Udara $\left({ }^{\circ} \mathrm{C}\right)$ & 32,2 & 29,9 & 31,8 \\
\hline
\end{tabular}

Menurut Odum (1996) intensitas cahaya mempengaruhi pola penyebaran organisme. Ada sebagian organisme yang menyukai cahaya dengan intensitas cahaya yang besar, namun ada juga organisme yang lebih menyukai cahaya yang redup. Berdasarkan hasil pengukuran dilapangan memperlihatkan rata-rata intensitas cahaya yang tidak terlalu besar, sesuai dengan kehidupan gastropoda.

Pengukuran kelembaban udara dilakukan pada semua zona penelitian berkisar antara 71\%-85\%. Kelembaban tertinggi ditemukan pada zona 2 karena pengukuran di lakukan pada pagi hari.
Kelembaban terendah di temukan pada zona 3 karena di lakukan pada siang hari.

Menurut Dharma gastropoda mampu hidup pada lingkungan dengan suhu tanah $12^{\circ} \mathrm{C}$ $43^{\circ} \mathrm{C}$. Hal ini menunjukkan bahwa kisaran suhu pada setiap zona penelitian masih berada dalam batas toleransi bagi kehidupan gastropoda.

Menurut Rosanti (2010) pH 5-9 masih dapat mendukung kehidupan gastropoda. Jika nilai $\mathrm{pH}$ kurang dari 4 mengakibatkan kematian pada gastropoda, sedangkan $\mathrm{pH}$ lebih dari 9,5 mengakibatkan gastropoda tidak 
produktif. Pengukuran nilai $\mathrm{pH}$ pada semua zona penelitian berkisar antara 5,3-5,7.

Menurut Satria (2014) salinitas yang optimal untuk kehidupan gastropoda berada pada kisaran 2834(\%). Menurut Russel (1983), Kisaran salinitas untuk kehidupan gastropoda di hutan mangrove 5-75 \%o. Hasil pengukuran salinitas pada lokasi penelitian berkisar antara 13,3-15,7 \%o masih cocok untuk pertumbuhan dan reproduksi gastropoda. Salinitas dikategorikan rendah karena lokasi penelitian tidak berhadapan langsung dengan laut sehingga dipengaruhi oleh air tawar dari aliran muara sungai.

Kisaran nilai rata-rata suhu udara masih tergolong baik bagi kehidupan gastropoda. Hal ini berkaitan dengan yang dikatakan oleh Odum (1996), bahwa kisaran suhu yang layak untuk pertumbuhan dan reproduksi gastropoda pada umumnya adalah $25^{\circ} \mathrm{C}-32 \%^{\circ} \mathrm{C}$.

\section{Indeks Keanekaragaman Jenis}

Keanekaragaman jenis dapat diartikan sebagai jumlah jenis diantara jumlah total individu dari seluruh jenis yang ada. Kisaran nilai indeks keanekaragaman jenis menurut Shannon-Wiener yaitu: $\mathrm{H}^{\prime}>3$ : Keanekaragaman tinggi, $1<\mathrm{H}^{\prime} \leq 3$ : Keanekaragaman sedang, $\mathrm{H}^{\prime}<1$ : Keanekaragaman rendah. Suatu komunitas dikatakan memiliki keanekaragaman jenis yang tinggi apabila komunitas tersebut disusun oleh banyak jenis. Sebaliknya suatu komunitas dikatakan memiliki keragaman jenis rendah jika komunitas tersebut disusun hanya oleh sedikit jenis tertentu.

Tabel 3. Indeks Keanekaragaman Jenis Gastropoda Pada Ekosistem Hutan Mangrove Desa Sebubus Kecamatan Paloh Kabupaten Sambas (Species Diversity Index of Gastropods in Mangrove Forest Ecosystems Sebubus Village, Paloh District, Sambas District)

\begin{tabular}{lccc}
\hline Zona & $\mathbf{1}$ & $\mathbf{2}$ & $\mathbf{3}$ \\
\hline Nilai $(\mathrm{H})$ & 0,83 & 0,73 & 0,79 \\
Kriteria & Rendah & Rendah & Rendah \\
\hline
\end{tabular}

Berdasarkan hasil analisis data indeks keanekaragaman jenis pada tabel 3 , setiap zona penelitian memiliki nilai yang berbeda-beda. Berdasarkan nilai tersebut keanekaragaman jenis di setiap zona pengamatan dikategorikan memiliki keanekaragaman rendah, karena pada lokasi penelitian telah terjadinya penurunan keanekaragaman jenis disebabkan oleh adanya tekanan lingkungan yang sepanjang waktu selalu berubah dan pengaruh dari aktivitas manusia yang seiring dengan perkembangan pembangunan. Pembukaan tambak di sebelah hutan mangrove oleh DKP (Dinas Kelautan dan Perikanan) dan pemanfaatan hasil jenis gastropoda tengkuyung (Cerithidea obtuse) untuk dikonsumsi langsung maupun dijual, 
mengakibatkan tidak adanya keselarasan dalam menjaga dan melestarikan jenis gastropoda yang ada pada ekosistem hutan mangrove Desa Sebubus Kecamatan Paloh Kabupaten Sambas.

Menurut Susiana (2011) hutan mangrove alami, gastropoda cenderung seragam dan memiliki keanekaragaman sedang disebabkan oleh konsentrasi kandungan parameter kualitas tanah dalam hal ini $\mathrm{pH}$ berkisar 7,99-8,13. Menurut Rosanti (2010) pH 5-9 masih dapat mendukung kehidupan gastropoda. Faktor tingginya indeks keanekaragaman jenis pada hasil penelitian Susiana (2011) karena kondisi mangrove yang masih baik, sehingga memungkinkan gastropoda untuk hidup dengan memanfaatkan serasah mangrove sebagai makanannya. Serasah mempunyai peranan penting sebagai produksi bahan organik karena bahan organik merupakan dasar rantai makanan. Kurangnya aktivitas manusia pada hutan mangrove juga menjadi salah satu penyebab tingginya nilai indeks keanekaragaman jenis.

\section{Indeks Kelimpahan Jenis}

Kelimpahan jenis merupakan banyaknya jenis gastropoda yang ditemukan pada setiap stasiun. Kelimpahan jenis gastropoda dihitung berdasarkan banyaknya individu.

Tabel 4. Rekapitulasi Indeks Kelimpahan Jenis Gastropoda pada Zona 1, 2 dan 3 (Recapitulation of Species Abundance Index Gastropod on zone 1, 2 and 3)

\begin{tabular}{|c|c|c|c|c|c|c|c|}
\hline \multirow{3}{*}{ No } & \multirow{3}{*}{ Nama Jenis } & \multicolumn{5}{|c|}{ Zona } & \\
\hline & & \multicolumn{2}{|c|}{1} & \multicolumn{2}{|c|}{2} & \multicolumn{2}{|c|}{3} \\
\hline & & $\mathrm{Ki}$ & $\mathrm{KR}(\%)$ & $\mathrm{Ki}$ & $\mathrm{KR}(\%)$ & $\mathrm{Ki}$ & KR (\%) \\
\hline 1 & Chicoreus capucinus & 1,6 & 10,46 & 0,1 & 0,95 & 0,5 & 0,16 \\
\hline 2 & Nerita balteata & 3,9 & 25,49 & 0,3 & 2,86 & 0,1 & 0,63 \\
\hline 3 & Neritina cornисоріа & 0,7 & 4,58 & 0,2 & 1,90 & - & - \\
\hline 4 & Nerita violacea & 0,3 & 1,96 & 0,3 & 2,86 & 0,1 & 0,63 \\
\hline 5 & Cerithideopsilla alata & 0,5 & 3,27 & 0,3 & 2,86 & 0,6 & 3,80 \\
\hline 6 & Cerithidiopsis quoyii & 0,2 & 1,30 & - & - & - & - \\
\hline 7 & Cerithidea obtuse & 0,1 & 0,65 & 0,6 & 5,71 & 1,1 & 6,97 \\
\hline 8 & Littoraria scabr & 2,5 & 16,34 & 2,1 & 20 & 0,4 & 2,53 \\
\hline 9 & Littoraria undulata & 0,3 & 1,96 & 0,4 & 3,81 & 0,1 & 0,63 \\
\hline 10 & Littoraria carinifera & - & - & - & - & 0,1 & 0,63 \\
\hline 11 & Nassarius dorsatus & - & - & - & - & 0,2 & 1,27 \\
\hline 12 & Cassidula aurisfelis & 4,6 & 30,07 & 5,0 & 47,62 & 6,9 & 43,67 \\
\hline 13 & Ellobium aurisjudae & 0,1 & 0,65 & 0,2 & 1,90 & 0,2 & 1,27 \\
\hline 14 & Cassidula nucleus & 0,3 & 1,96 & 1,0 & 9,52 & 2,3 & 14,56 \\
\hline 15 & Pythia plicata & 0,2 & 1,30 & - & - & 0,7 & 4,40 \\
\hline \multirow[t]{3}{*}{16} & Ellobium gangeticum & - & - & - & - & 2,5 & 15,82 \\
\hline & Jumlah Total & 15,3 & 100 & 10,5 & 100 & 15,8 & 100 \\
\hline & Jumlah Spesies & \multicolumn{2}{|c|}{13} & \multicolumn{2}{|c|}{11} & \multicolumn{2}{|c|}{14} \\
\hline
\end{tabular}

Keterangan:

$\mathrm{Ki}=$ Kelimpahan Individu, KR = Kelimpahan Relatif 
Berdasarkan hasil perhitungan kelimpahan individu pada zona 1,2 dan 3 berkisar antara 10,5-15,3 individu $/ \mathrm{m}^{2}$ dikategorikan memiliki kelimpahan jarang disebabkan oleh aktivitas manusia pada kawasan mangrove. Pembukaan tambak dan pemanfaatan hasil jenis tengkuyung (Cerithidea obtuse) untuk dikonsumsi langsung maupun dijual menyebabkan kelimpahan jarang. Menurut Haris et al., (2010) kelimpahan jarang merupakan kehadiran individu atau spesies dengan nilai kelimpahan yang berkisar antara 3-44,2 individu/ $\mathrm{m}^{2}$. Kelimpahan relatif terbesar adalah Cassidula aurisfelis yang ditemukan pada setiap zona penelitian berkisar antara 30,07-47,62\%.

\section{Indeks Kemerataan Jenis dan Indeks Dominasi}

Indeks kemerataan jenis digunakan untuk mengetahui gejala dominasi diantara setiap jenis dalam suatu lokasi. Indeks dominansi digunakan untuk memperoleh informasi mengenai spesies yang mendominasi pada suatu populasi.

Tabel 5. Indeks Kemerataan Jenis dan Indeks Dominasi Gastropoda Pada Ekosistem Hutan Mangrove Desa Sebubus Kecamatan Paloh Kabupaten Sambas (Species Evenness Index and Domination Index of Gastropods in Mangrove Forest Ecosystems Sebubus Village, Paloh Subdistrict, Sambas District)

\begin{tabular}{lccc}
\hline Zona & $\mathbf{1}$ & $\mathbf{2}$ & $\mathbf{3}$ \\
\hline Nilai (E) & 0,32 & 0,30 & 0,30 \\
Nilai (C) & 0,20 & 0,28 & 0,25 \\
\hline
\end{tabular}

Menurut Odum (1996), indeks kemerataan kurang dari 0,50 maka ekosistem tersebut berada dalam kondisi tertekan dan mempunyai kemerataan rendah. Indeks kemerataan jenis menunjukan kelimpahan individu merata atau tidak. Hasil analisis kemerataan (E) pada tiap zona berkisar dari $0,30-0,32$, jadi tiap zona penelitian termasuk kategori komunitas tertekan memiliki kemerataan yang rendah. Kriteria ini menunjukan bahwa tidak ada sebaran yang merata dan menunjukan ada dominansi jenis.

Menurut Odum (1996), kriteria indeks dominansi kurang dari 0.5 maka tidak ada jenis yang mendominasi.
Kriteria indeks dominansi lebih dari 0.5 maka ada jenis yang mendominasi.

Berdasarkan hasil analisa nilai indeks dominansi pada setiap zona penelitian memiliki nilai dominansi yang berbeda-beda berkisar 0,20-0,28. Berdasarkan kriteria nilai indeks menggambarkan bahwa tidak ada jenis gastropoda yang dominan karena nilai yang didapat mendekati kriteria 0 ( $\mathrm{Nol})$. Aktivitas manusia di sekitar kawasan hutan mangrove seperti pembuatan tambak, serta pemanfaatan gastropoda oleh masyarakat sekitar juga memberikan pengaruh terhadap keberadaan gastropoda. Menurut Yanto et., al (2016), indeks kemerataan mendekati 0 (Nol), maka organisme 
pada komunitas tidak merata disebakan ekosistem mangrove yang masih alami.

\section{Indeks Kesamaan Jenis}

Indeks kesamaan jenis digunakan untuk membandingkan antar zona pengamatan. Menghitung indeks kesamaan (IS) antara dua zona. Hasil perhitungan kesamaan gastropoda disajikan pada tabel 6 .

Tabel 6. Rekapitulasi Nilai Indeks Kesamaan Jenis di Setiap Zona penelitian (Recapitulation of the Similarity Index Value in each research zone)

\section{Keterangan}

Zona 1 - Zona 2

Zona 2 - Zona 3

Zona 1 - Zona 3

\section{Indeks Kesamaan Jenis}

$91,67 \%$

$80,00 \%$

$81,48 \%$
Berdasarkan hasil analisa indeks kesamaan jenis pada tabel 6 terdapat nilai kesamaan jenis gastropoda yang berbedabeda ditemukan pada setiap zona penelitian berkisar 80,00\%-91,67\%, dikategorikan memiliki indeks kesamaan sangat tinggi.

Faktor yang mempengaruhi tingginya indeks kesamaan jenis antara semua zona karena tipe dari hutan mangrove dan letak lokasi penelitian yang faktor lingkungan tidak jauh berbeda, dan dekat dengan muara sungai sehingga masih terkena pasang surut air yang sama.

\section{KESIMPULAN}

Gastropoda yang ditemukan pada ekosistem hutan mangrove Desa Sebubus Kecamatan Paloh Kabupaten Sambas sebanyak 16 jenis dan 6 famili. Nilai indeks keanekaragaman gastropoda pada zona 1, 2 dan 3 berkisar antara 0,73 - 0,80 termasuk kategori rendah. Nilai indeks kelimpahan individu di ketiga zona penelitian berkisar antara 10,5-15,8. Nilai kemerataan jenis pada tiap zona berkisar dari 0,30-0,32, sehingga setiap zona penelitian termasuk memiliki nilai dominansi yang berbeda-beda berkisar 0,20-0,28 dikategorikan dominansi rendah.
Perbandingan indeks kesamaan jenis setiap zona berkisar antara 80,00\% 91,67\% di kategorikan kesamaan jenis sangat tinggi.

\section{SARAN}

1. perlunya dilakukan pengukuran parameter lingkungan dilakukan dalam jangka waktu yang lama untuk mendapatkan hasil yang lebih akurat.

2. Perlunya kesadaran dari masyarakat untuk menjaga ekosistem hutan mangrove sehingga dapat melindungi keanekaragaman jenis gastropoda dan hewan lain yang hidup di dalam ekosistem tesebut.

3. Perlu adanya penelitian lanjutan dalam jangka waktu yang lama mengenai pola sebaran gastropoda yang ada pada ekosistem hutan mangrove Desa sebubus Kecamatan Paloh Kabupaten Sambas.

\section{UCAPAN TERIMA KASIH}

Ucapan terima kasih penulis sampaikan kepada kedua orangtua yang telah memberikan dukungan baik secara moril maupun materil. Penulis juga mengucapkan terima kasih kepada Comdev \& Outreaching Universitas Tanjungpura yang telah memberikan 
beasiswa selama masa studi dan Bapak Darmawan selaku pengelola Kelompok Masyarakat Kalilaek \& Green Leaf yang telah membantu selama proses penelitian. Penelitian ini dapat terlaksana atas bantuan berbagai pihak yang tidak bisa disebutkan satu persatu, untuk itu penulis mengucapkan terima kasih kepada semua pihak yang telah membantu penelitian ini.

\section{DAFTAR PUSTAKA}

Anwar JSJ, Damanik dan Hisyam M. 1984. Ekologi Ekosistem Sumatera. Yogyakarta: Universitas Gadjah Mada Press.

Dharma B. 1988. Siput dan Keong Indonesia (Indonesia Shell). Jakarta: PT.Sarana Graha.

Haris A, Ambo T, dan Ammar A. 2010. Kelimpahan dan Distribusi Isis Hippuris di perairan Spramonde Makassar. Jurnal ilmu kelautan dan perikanan. 20 (1):8-16.

Islami MM. 2015. Distribusi Spasial Gastropoda Dan Kaitannya dengan Karakteristik Lingkungan dipesisir Pulau Nusalaut Maluku Tengah. Jurnal ilmu kelautan dan teknologi kelautan. 7(1): 365-378.

Nurrudin, Hamidah A, dan Kartika WD. 2015. Keanekaragaman Jenis Gastropoda di sekitar Tempat Pelelangan Ikan (TPI) Parit 7 Desa Tungkal I Tanjung Jabung Barat. Blospecles. 8(2): 51-60

Odum EP. 1996. Dasar-Dasar Ekologi. Penerjemahan: Samingan T dan B. Srigandono.Yogyakarta: Gajahmada University Press.

Poutiers JM. 1998. The Living Marine Resources of The Western Central Pacific. FAO Species Identification Guide for Fishery Purposes 1(4): 363-648.
Rosanti D. 2010. Struktur Populasi Assiminea brevicula pada Zona Avicenia Hutan Mangrove Desa Sungai Batang Kabupaten Oki. Sainmatika. 7(2): 59-65.

Rusnaningsih. 2012. Struktur Komunitas Gastropoda dan Studi Populasi Cerithidea Obtusa (Lamarck 1822) di Hutan Mangrove Pangkal Babu Kabupaten Tanjung Jabung Barat, Jambi. Jurnal Biogenesis. 2(1): 2529

Russel. 1983. The Molusca. New York: Syrause University Press.

Satria M. 2014. Keanekaragaman dan Distribusi Gasropoda di Perairan Desa Berakit Kabupaten Bintan. Repository Fikp UMRAH.

Shannon CE dan Winner W. 1963. The Mathematical Theory of Communication. Urban: University Illinois Press.

Susiana. 2011.Diversitas Dan Kerapatan Mangrove Gastropoda, dan Bivalvia di Estuari Perencak, Bali. Jurnal: Agribisnis dan perikanan. 8(1): 110.

Tapilatu Y dan Pelasula D. 2012. Biota Penempel yang Berasosiasi dengan Mangrove di Teluk Ambon Bagian Dalam. Jurnal Ilmu dan Teknologi Kelautan Tropis 4(2): 267-279.

Yanto R, Pratomo A, dan Irawan H. 2016. Keanekaragaman Gastropoda Pada Ekosistem Mangrove Pantai Masiran Kabupaten bintang. Repository Fikp UMRAH.

Zulheri D, Irawan H, dan Muzahar. 2014. Keanekaragaman Gastropoda Pada Ekosistem Mangrove dan Lamun pulau Dompak Kota Tanjungpinang.Repository Fikp $U M R A H$. 